\title{
Serum Calcium Measurement
}

National Cancer Institute

\section{Source}

National Cancer Institute. Serum Calcium Measurement. NCI Thesaurus. Code C61020.

A quantitative measurement of the amount of calcium present in a sample of serum. 